\title{
Meta
}

Journal des traducteurs

Translators' Journal

\section{Process-Oriented Translator Training and the Challenge for E-Learning}

\section{Gary Massey}

Volume 50, numéro 2, avril 2005

Processus et cheminements en traduction et interprétation Processes and Pathways in Translation and Interpretation

URI : https://id.erudit.org/iderudit/011006ar

DOI : https://doi.org/10.7202/011006ar

Aller au sommaire du numéro

Éditeur(s)

Les Presses de l'Université de Montréal

ISSN

0026-0452 (imprimé)

1492-1421 (numérique)

Découvrir la revue

Citer cet article

Massey, G. (2005). Process-Oriented Translator Training and the Challenge for E-Learning. Meta, 50(2), 626-633. https://doi.org/10.7202/011006ar
Résumé de l'article

De nouveaux modèles cognitifs représentent la compétence de traduction comme un processus dynamique constitué d'un certain nombre de sous-composants interactifs et interdépendants, ce qui semble avoir entraîné un glissement vers une formation en traduction orientée processus, et avoir créé un climat favorable à l'introduction de méthodes socio-constructivistes dans l'enseignement de la traduction. Cet article examine l'émergence d'un nouveau type de formation en traduction, ainsi que le défi qu'il lance à la formation en ligne, qui - en vertu du rôle clé des outils TIC dans le processus de traduction - est bien placée dans l'enseignement constructiviste de la traduction orientée processus.
Ce document est protégé par la loi sur le droit d'auteur. L'utilisation des services d’Érudit (y compris la reproduction) est assujettie à sa politique d'utilisation que vous pouvez consulter en ligne.

https://apropos.erudit.org/fr/usagers/politique-dutilisation/ 


\title{
Process-Oriented Translator Training and the Challenge for E-Learning
}

\author{
GARY MASSEY \\ Zurich University of Applied Sciences, Winterthur, Switzerland \\ msy@zhwin.ch
}

\section{RÉSUMÉ}

De nouveaux modèles cognitifs représentent la compétence de traduction comme un processus dynamique constitué d'un certain nombre de sous-composants interactifs et interdépendants, ce qui semble avoir entraîné un glissement vers une formation en traduction orientée processus, et avoir créé un climat favorable à l'introduction de méthodes socio-constructivistes dans l'enseignement de la traduction. Cet article examine l'émergence d'un nouveau type de formation en traduction, ainsi que le défi qu'il lance à la formation en ligne, qui - en vertu du rôle clé des outils TIC dans le processus de traduction - est bien placée dans l'enseignement constructiviste de la traduction orientée processus.

\begin{abstract}
Recent cognitive models present translation competence as an open-ended process encompassing a number of mutually dependent, interacting sub-components, which seems to have resulted in a shift towards process-orientation in translator training and created a favourable climate for introducing social constructivist methods to translator education. This paper considers the emergence of a new translator training paradigm and the challenge it poses for e-learning, which by virtue of the key role played by ICT tools in the translation process is well positioned to become an established, integral part of process-oriented, constructivist translator education.
\end{abstract}

\section{MOTS-CLÉS/KEYWORDS}

translation competence, process-oriented translator training, constructivism, e-learning

\section{Introduction}

Over the last decade or so, a considerable amount of time and attention has been devoted to debating the relative merits of product- and process-oriented translator training. Recent cognitive models present the acquisition of translation competence as an open-ended process embracing a variety of mutually dependent, interacting sub-components. The attendant focus on process-orientation raises important pedagogical issues, with key implications both for translator training in general and for the appropriate design and deployment of e-learning solutions in translation programmes.

\section{Translation competence}

Nowadays, most practitioners and theorists agree that translation competence defined by PACTE as "the underlying system of knowledge and skills needed to be able to translate" (2000: 100) - goes beyond the skills normally associated with 
bilingualism and communication in a foreign language. Translation is a unique mode of language use (Neubert 1997: 23). Even superficial observations of the translation process show translators mobilizing very diverse, interdisciplinary skills and knowledge to accomplish their tasks: knowledge of languages, subject and real-world knowledge, research skills and qualities such as creativity and problem-solving strategies (Presas 2000: 28).

Cognitive models recently used to define (PACTE 2000; Neubert 1997, 2000) and evaluate (Orozco 2000; Adab 2000) translation competence postulate that it is made up of a number of continuously evolving sub-competences feeding into and off one another, each with a cluster of sub-components. PACTE for instance, identifies six such sub-competences. The first four are largely self-explanatory: communicative competence, comprising the knowledge system and skills needed for linguistic communication; extra-linguistic competence, covering general world knowledge, specific subject knowledge and cultural knowledge in the source and target cultures; psychophysiological competence, "the ability to use all kinds of psychomotor, cognitive and attitudinal resources" (PACTE 2000: 102); and instrumental-professional competence, composed of knowledge and skills related to using the tools of the translator's trade and to the translation profession as a whole. The remaining two occupy central positions in the actual accomplishment of translational objectives. Transfer competence, recognized by both PACTE (2000: 102) and Neubert (2000: 6) as the one which integrates all the others and as the key distinguishing provenance of the translator, embodies the ability to bring about an adequate transfer from the source to the target text, establishing bridges or linking mechanisms between the translator's working languages (Presas 2000: 27). Finally, strategic competence encompasses all procedures used to solve problems during the translation process, and can thus be seen as the ability to control the interaction between all the other sub-competences to effect transfer.

Dynamic and open-ended, these models present translation competence as a process of building and rebuilding knowledge and skills. As they develop into fullyfledged professionals, translators both pick up sub-competences they never had before and actually restructure the new and existing ones in a way that best serves transfer competence, thereby demonstrating the acquisition and application of strategic competence (PACTE 2000: 103; Presas 2000: 29). Such a view is supported by Shreve, who suggests that translators' exposure to an increasing variety of translation situations leads to changes in the way they conceive of translation, with knowledge structures both becoming richer and being organized differently (1997: 124f.). This would account not only for non-professionals and professionals deploying appropriate problem-solving strategies differently (Fraser 1999), but also for the fact that professionals appear to have a far greater awareness of contextual and pragmatic issues: TAP research has shown that while learners and novices tend to concentrate on lexical and syntactic solutions to perceived problems, professional translators will check for stylistic and text-type adequacy and advanced trainees reflect on their audience (Kussmaul 1995: 82f; Fraser 2000: 59; Shreve 1997: 135). The corollary, Shreve argues, is that "professional translation [...] can be acquired by only undergoing certain kinds of deliberately sought out communicative experiences" (1997: 125), a point equally stressed by Robinson (Robinson 1997: 94-123). Indeed, the centrality of experience for learning in general would seem to be borne out by the latest empirical 
findings in brain research: knowledge is dependent on our experience of the world (Spitzer 2002: 447); we learn because our brains are "rule extraction machines" (Spitzer 2002: 75, 2004: 71), inductively deriving rules, methods and strategies from the processing of examples provided by the world around us (Spitzer 2002: 76, 2004: 72).

\section{Implications for translator training}

The above carries clear implications for the training of translators. Firstly, it is important to make trainees fully aware of what the various sub-components of translation competence are and how they relate to one another in the translation process (Adab 2000: 227), of their workings and interactions in what Neubert calls the "complex interdiscipline of translation" (Neubert 2000: 17). Only then can they be expected to use them properly and purposefully. Secondly, if we accept that translation competence and its acquisition are dynamic processes, then the training of translators must necessarily be process-oriented and focus in large part on the development of procedural knowledge and procedural competence. Thirdly, trainees have to be exposed to as large and varied a range of authentic experiences of the translation process as possible.

There is nothing particularly new in this. The need for an integrated approach to translation studies and the concept of translation as an interdiscipline were already being discussed in the 1980s by Snell-Hornby (1988) and are now reflected in the structure and content of many translator training programmes. Process-orientated translator training has been advocated to varying degrees by a number of trainers (e.g. Gile 1994, 1995; Kiraly 2000, 2003; Kussmaul 1995; Neubert 2000; Robinson 1997), and with it the need to break away from a traditionally prescriptive and product-oriented translation pedagogy (Fox 2000: 115).

Likewise, the active involvement of students in authentic, experiential learning situations is a basic tenet of constructivist educational theories, according to which learning is essentially an interactive, collaborative, "socio-personal process" (Kiraly 2003: 29) whereby learners construct their own knowledge. The fairly widespread practice of having students complete collaborative, often genuine, project-based assignments as part of their courses, with instructors acting as coaches, represents an uncontroversial form of constructivism in translator training institutions.

Yet, as Kiraly points out $(2000,2003)$, there is ample room for the more consistent implementation of social constructivist approaches in translator training, with large parts of the curriculum still dominated by teacher-centred, transmissionist educational methods. He calls for "a much-needed paradigm shift in translator education" (2003: 27) from a positivist epistemology which holds that instructors, having acquired expert knowledge, have access to an objective truth which they must impart to their students, to one where students are expected to discover knowledge for themselves in a learner-centred environment by collaboratively participating in the authentic activities of professional translators (2003: 28f.). In doing so, Kiraly maintains, students will "move from the periphery of the community of professional translators into a position of full membership of that community" (2003: 29). Students must emancipate themselves from their instructors "if they are to emerge from the educational situation as self-confident translation experts, prepared to think for themselves, to work as members of a team, to assume responsibility for their own 
work, to assess the quality of their own performance and to continue learning once they leave the institution" (Kiraly 2003: 31). The goals of translator education must be to help students develop their own self-concept and to assist "in the collaborative construction of individually tailored tools that will allow every student to function within the language mediation community upon graduation" (Kiraly 2000: 49). The issue here, of course, is one of degree: Kiraly believes that learning should take place as a collaborative social process in all translation contact hours, not just in special project work assignments. In such an environment, the instructors would assume the role of facilitators working together with students on authentically situated tasks, supporting students as necessary in their search for solutions - Kiraly uses the constructivist term "scaffolding" (2000: 45ff.) - but with the ultimate aim of helping the trainees to help themselves.

The case for a broader social constructivist approach to translator training is a persuasive one. Kiraly himself quotes a study by Johnson \& Johnson ${ }^{1}$ in support of his contention that co-operative approaches to learning are more effective at promoting learning achievement than competitive or individualized ones (2000: 37). Furthermore, collaboration is an indisputable fact of professional translation in the real world. Professional translators are commissioned by clients to translate texts for particular purposes and readerships within the target culture. 0ther agents will also be involved: Holz-Mänttäri's (1984: 106ff.) famous model of translational action identifies a functional network of up to six potential roles and actors in the overall translation process, only one of which is the translator. Working from this model, Risku and Freihoff make a plea for increased awareness amongst translators of their role as "co-operation partners" (Risku \& Freihoff 2000: 49, 59). And since brain research tells us that we learn by acting (Spitzer 2002: 421), the argument in favour of students' active involvement in an authentically situated learning environment appears compelling. Seen from this perspective, a more widespread use of constructivist techniques in the training of translators would be desirable - not only in conventional face-to-face lessons, but also in the new environments offered by e-learning.

\section{The challenge for e-learning}

Trainers and practitioners have long identified the need to integrate training in the use of computer-based tools and resources into translation syllabuses and curricula (Kiraly 2000: 123ff.; Lee-Jahnke 1998; Massey 1998: 139ff.; Owens 1996: 35). It would therefore be reasonable to assume that translator training institutions have taken advantage of the opportunities presented by e-learning to offer a variety of online instruction modules and courses to their students. Yet, a survey conducted in 2001 showed relatively few courses of this sort, with a web search of 121 translation schools rendering only a handful of online programmes (Pym et al. 2003: 84), while a recently published report on an online symposium dealing with the subject brings only a limited number of offerings to light (Pym et al. 2003: 65-84).

This is all the more surprising because trainers who do tutor or moderate e-learning courses are apt to stress the benefits of teaching in an online environment where students must use the very tools professional translators handle every day of their working lives (Folaron 2003: 65; Schiavi 2003: 77). In Debbie Folaron's words: "Honing the necessary electronic skills inevitably becomes part and parcel of the 
course itself" (2003: 65). Moreover, given that the "translator's tools are very much a part of the translation process" (Kiraly 2000: 124), e-learning could provide precisely the kind of learning environments that process-orientation and constructivist approaches in translator training would require: "Knowledge-in-action is mediated by the tools we use; thus an important part of the education of any professional must entail practical training in learning how to use the everyday tools of the profession" (Kiraly 2000: 124).

In particular, e-learning can and does offer workable collaborative, authentically situated solutions for teaching instrumental-professional competence. This has been recognized by the institutions participating in "eCoLoRe" ("eContent Localization Resources for Translator Training”), a large-scale EU-sponsored international project launched in 2004 to support ICT training for translators. Other institutions have built appropriate online units into their standard translation curricula, such as the courses in revision techniques and electronic tools for translators at the Universidad Metropolitana in Caracas (Rodríguez 2003: 72) or the "Tools for Translators" module at Zurich University of Applied Sciences, Winterthur. Nevertheless, such initiatives appear to be the exception rather than the rule, and the fact remains that e-learning is challenged to realize its potential as an integral part of process-oriented translator training.

Part of that challenge involves overcoming misconceptions and creating a more extensive awareness among instructors and learners of what e-learning platforms are capable of. By far the most widespread use of ICT in education is to disseminate information, distribute documentation and transfer assignments between teachers and students, which amounts to no more than an efficient, de-centralized form of classroom management. To equate this with e-learning, as many teachers seem to, is to reduce it to an electronic postal service and notice-board. Students, too, are inclined to misunderstand the new medium: when evaluating their course, participants in Zurich University of Applied Sciences' “Tools for Translators" module have repeatedly asked for content to be made available in printable handout form and for the various web pages to be numbered consecutively. Neither instructors nor students are conscious of the vast potential for constructivist, learner-centred exploration and discovery presented by hypertext linking, non-linear sequencing and ready online access to the vast resources of the extra-institutional world ${ }^{2}$. Yet, this is where elearning has a distinct advantage over the traditional translation classroom, enabling courses to be designed which are embedded in a realistically situated environment and whose non-linearity authentically reflect the role-switching (Sager 1992: 112f.) typical of genuine working practices, as translators constantly shift attention between source text, target text and an array of resources.

It is equally important to design e-learning courses that are highly interactive and which permit a maximum degree of tutor-learner and learner-learner collaboration. Studies on learner drop-out rates show community-building through asynchronous and synchronous interactivity. A ready access to tutors and a strong identification between instructors and students proves to be a powerful motivational factor for e-learning participants (Frankola 2004), the latter point being supported by results from brain research indicating that learning will be most successful where a bond exists between learners and teachers (Spitzer 2002: 411ff.). Such insights have led to appropriately scaffolded collaborative assignments involving groups of learners and 
facilitators, the provision of online forums for both task-related and private interaction amongst participants, and the blending of online sequences with regular live or faceto-face interactive sessions being considered best practice in e-learning pedagogy (Folaron 2003: 65, 68; Horton 2000: 433ff.; Seufert 2001: 27, 57).

Once again, student evaluations of the "Tools for Translators" module at Zurich University of Applied Sciences, Winterthur ${ }^{3}$, strongly support this perception: measured on a scale of 1 (low) to 6 (high), satisfaction with the learner-centred collaborative assignments, tutor-student interaction and peer interaction on the course averaged out at 5.20, 5.76 and 5.15 respectively. It remains to be seen whether the skills learned on this module lead to better translation performances inside and outside the institutional framework. The evidence suggests, however, that they should, with students equipped with the sort of collaborative ICT, resource-use and problemsolving skills they will need as they gradually begin to find their place within the professional community of translators.

\section{Conclusion}

Cognitive research on translation competence appears to have resulted, at least in the literature concerned with translation pedagogy, in a growing shift towards processorientation in the training of translators. This, in turn, has created a favourable climate for introducing social constructivist methods to translator education, as trainers become increasingly aware of the need for students to work on realistically embedded tasks within a genuinely learner-centred environment. The widespread inclusion of collaborative, project-based assignments in translator training curricula is perhaps an early indication that changes are already under way. But the emergence of a new translator training paradigm poses a challenge for e-learning. Given the pivotal role of online, computer-based tools and resources in the translation process, e-learning solutions are extremely well positioned to become an established, integral part of process-oriented, constructivist translator education: collaborative, authentic, situated and purposeful. It is a challenge to which institutions must rise by adopting a coherent e-learning strategy and deploying the necessary resources to see it through.

\section{NOTES}

1. Johnson, D W. \& R. T. Johnson (1991): Learning Together and Alone, Englewood Cliffs, N.J.: Prentice Hall. The cited work is a meta-study of over 500 research projects investigating the relative success of collaborative, competitive and individualized approaches to learning.

2. This is one area in which e-learning has developed a wholly new, unique activity unknown to other forms of instruction, the WebQuest. The WebQuest is described by its inventor, Bernie Dodge, as "an inquiry-oriented activity in which some or all of the information that learners interact with comes from resources on the internet [...]" (Seufert et al. 2001: 120f.).

3. The module has been consistently evaluated by questionnaire since its launch in November 2002. To date, the course has been completed by 73 students and evaluated by 45 respondents, a return rate of $61.6 \%$. 


\section{REFERENCES}

AdAB, B. (2000): “Evaluating Translation Competence,” in: C. Schäffner \& B. AdAB (eds.) Developing Translation Competence, Amsterdam/Philadelphia: John Benjamins, p. 215-228.

Folaran, D. (2003): "Notes on Translator Training," in A. Pym, C. Fallada, J. R. Biau \& J. Orenstein (eds.) Innovation and E-Learning in Translator Training: Reports on Online Symposia, Tarragona: Universitat Rovira I Virgili, p. 65-69.

Fox, Olivia (2000): "The Use of Translation Diaries in a Process-Oriented Translation Teaching Methodology," in: C. Schäffner \& B. Adab (eds.) Developing Translation Competence, Amsterdam/Philadelphia: John Benjamins, p. 115-130.

Frankola, K. (2004): "Why Online Learners Drop Out," in Workforce Management, <http:// www.workforce.com/archive/feature/22/26/22/index.php>.

Fraser, J. (1999): "The Translator and the Word: The Pros and Cons of Dictionaries in Translation,” in: G. Anderman \& M. Rogers (eds.) Word, Text, Translation: Liber Amicorum for Peter Newmark, Clevedon: Multilingual Matters, p. 25-34.

Fraser, J. (2000): “The Broader View: How Freelance Translators Define Translation Competence," in: C. SCÄFfner \& B. AdAB (eds.) Developing Translation Competence, Amsterdam/ Philadelphia: John Benjamins, p. 51-62.

Gile, D. (1994): “The Process-Oriented Approach in Translation Training," in C. Dollerup \& A. LindegaArd (eds.) Teaching Translation and Interpreting 2: Insights, Aims, Visions, Amsterdam/Philadephia: John Benjamins, p. 107-112.

GiLE, Daniel (1995): Basic Concepts and Models for Interpreter and Translator Training, Amsterdam/ Philadephia: John Benjamins.

Holz-MäntTARI, J. (1984): Translatorisches Handeln. Theorie und Methode. Helsinki: Suomalainen Tiedeakatemia, Annales Academiae Scientiarum Fennicae B 226.

Horton, W. K. (2000): Designing Web-Based Training, New York: Wiley.

Kiraly, D. (2000): A Social Constructivist Approach to Translator Education: Empowerment from Theory to Practice, Manchester/Northampton: St. Jerome.

Kiraly, D. (2003): "From Teacher-Centred to Learning-Centred Classrooms in Translator Education: Control, Chaos or Collaboration?” in: A. Pym, C. Fallada, J. R. Biau \& J. Orenstein (eds.) Innovation and E-Learning in Translator Training: Reports on Online Symposia, Tarragona: Universitat Rovira I Virgili, p. 27-31.

Kussmaul, P. (1995): Training the Translator. Amsterdam/Philadelphia: John Benjamins.

Lee-Jahnke, H. (1998): "Moderne Hilfsmittel in der Übersetzungslehre am Fallbeispiel medizinische Übersetzung," in: H. LEE-JAHNKe (ed.) équivalences 97. Les outils informatiques au service de la traduction: théorie et pratique, Berne: ASTTI, p. 119-135.

MAssey Y. G. (1998): “Some aspects of computer-based translator training," in: H. LeE-JAHNKE (ed.) équivalences 97. Les outils informatiques au service de la traduction: théorie et pratique, Berne: ASTTI, p. 137-146.

Neubert, A. (1997): "Postulates for a Theory of Translation," in: J. M. Danks, G. M. Shreve, S. B. Fountain \& M. K. McBeath (eds.) Cognitive Processes in Translation and Interpreting, Thousand Oaks: Sage, p. 1-24.

Neubert, A. (2000): “Competence in Language, Languages, and in Translation," in: C. SchäFfner \& B. Adab (eds.) Developing Translation Competence, Amsterdam/Philadelphia: John Benjamins, p. 3-18.

Orozco, M. (2000): "Building a Measuring Instrument for the Acquisition of Translation Competence in Trainee Translators," in: C. SCHÄFfner \& B. AdAB (eds.) Developing Translation Competence, Amsterdam/Philadelphia: John Benjamins, p. 199-214.

Owens, Rachel (ed.) (1996): The Translator's Handbook. 3rd ed. London: ASLIB.

PACTE (2000): "Acquiring Translation Competence: Hypotheses and Methodological Problems of a Research Project," in: A. Beeby, D. Ensinger \& M. Presas (eds.) Investigating Translation: Selected Papers from the 4th International Congress on Translation, Barcelona, 1998, Amsterdam/Philadelphia: John Benjamins, p. 99-106. 
Presas, M. (2000): "Bilingual Competence and Translation Competence," in: C. Schäffner \& B. Adab (eds.) Developing Translation Competence, Amsterdam/Philadelphia: John Benjamins, p. 19-31.

Pym, A., C. Fallada, José Ramón Biau \& J. Orenstein (2003): Innovation and E-Learning in Translator Training: Reports on Online Symposia, Tarragona: Universitat Rovira I Virgili.

Risku, H. \& R. Freinoff (2000): "Kooperative Textgestaltung im translatorischen Handlungsrahmen," in: A. Chestermann, N. Gallardo, San Salvador \& Y. Gambier (eds.) Translation in Context: Selected Contributions from the EST Congress, Granada, 1998, Amsterdam/ Philadelphia: John Benjamins, p. 49-59.

Robinson, D. (1997): Becoming a Translator: An Accelerated Course. London/New York: Routledge. Rodriguez, M. (2003): "Notes on Translator Training," in: A. Pym, C. Fallada, J. R. Biau \& J. Orenstein (eds.) Innovation and E-Learning in Translator Training: Reports on Online Symposia, Tarragona: Universitat Rovira I Virgili, p. 72-73.

SAger, Juan C. (1992): “The Translator as Terminologist," in: C. Dollerup \& A. LoddgaArd (eds.) Teaching Translation and Interpreting: Training, Talent and Experience, Amsterdam/ Philadelphia: John Benjamins, p. 107-122.

Schiavi, G.(2003): “The Vincenza-CeTRA Project," in: A. Pym, C. Fallada, J. R. Biau \& J. Orenstein (eds.) Innovation and E-Learning in Translator Training: Reports on Online Symposia, Tarragona: Universitat Rovira I Virgili, p. 74-77.

Seufert, S. BACK, A. \& M. Häusler (2001): E-Learning - Weiterbildung im Internet, Kilchberg: SmartBooks.

Shreve, G. M. (1997): "Cognition and the Evolution of Translation Competence," in: J. M. Danks, G. M. Shreve, S. B. Fountain \& M. K. McBeath (eds.) Cognitive Processes in Translation and Interpreting, Thousand Oaks: Sage, p. 120-136.

Snell-Hornby, M. (1988): Translation Studies: An Integrated Approach, Amsterdam/Philadelphia: John Benjamins.

Spitzer, M. (2002): Lernen: Gehirnforschung und die Schule des Lebens, Heidelberg/Berlin: Spektrum Akademischer Verlag.

Spitzer, M. (2004): “Gehirnforschung und lebenslanges Lernen,” in: M. Franzen (ed.) Die Zukunft von eLearning. Neue Erkenntnisse aus Gehirnforschung, Pädagogik und Wirtschaft, Olten: Fachhochschule Solothurn Nordwestschweiz, p. 67-85. 